\title{
Higher Education in Times of Covid-19: Giving Online Feedback Implementation Another Look
}

\author{
Michael Hast ${ }^{1}$ \\ ${ }^{1}$ National Institute of Education, Nanyang Technological University, Singapore \\ Correspondence: Michael Hast, National Institute of Education, Nanyang Technological University, Singapore. \\ Tel: 65-6790-3205. E-mail: michael.hast@nie.edu.sg
}

Received: October 20, 2020

Accepted: November 9, $2020 \quad$ Online Published: November 15, 2020

doi:10.5539/hes.v11n1p1

URL: https://doi.org/10.5539/hes.v11n1p1

\begin{abstract}
This short reflection piece seeks to examine the importance of online feedback in light of higher education student experiences during times of Covid-19. In doing so, it seeks to address how online approaches need to be harnessed further to minimise experiences of 'missing out' of education. The review summarises key advantages provided by online feedback implementation at the university level. It then continues by outlining the main challenges in this domain - challenges that will be even more pertinent in the current climate. Finally, the conclusion offers some thoughts on how student engagement with online feedback might be fostered further, in the hopes of mitigating the interference emphasised by the current global situation.
\end{abstract}

Keywords: online feedback, engagement, motivation, review

\section{Introduction}

Within an increasingly digitally resourced world where technologies are rapidly changing (Abrahams, 2010; Altbach, Reisberg, \& Rumbley, 2009; Sarkar, 2012), higher education institutions globally are embracing technology-based approaches to support the ever-changing needs within the world (Laurillard, 2006; Selwyn, 2016; Turney, Robinson, Lee, \& Soutar, 2009; Walker, Voce, \& Ahmed, 2012). Not only is technology becoming more important from a future-directed perspective, but more and more students entering higher education are from the so-called net generation (Manuguerra \& Petocz, 2011; Prensky, 2012); young people who are highly comfortable with technology and who are looking for learning experiences that match these expectations (Bradwell, 2009; Gosper, Malfroy, \& McKenzie, 2013; Lai, 2011; McLoughlin \& Luca, 2006).

As a result, technology has increasingly found a determined place within higher education, including in the specific context of student assessments and assessment feedback (Ambler, Breyer, \& Young, 2014; Browne, Jenkins, \& Walker, 2006; Hepplestone, Holden, Irwin, Parkin, \& Thorpe, 2011). Assessments and feedback are integral to student achievement of educational goals and motivation (e.g. Brown, Peterson, \& Irving, 2009; Grieve, Padgett, \& Moffitt, 2016; Heinrich, Milne, \& Granshaw, 2012). They can promote self-regulated learning (Brown, Peterson, \& Yao, 2016), and student engagement is directly impacted by feedback (Ferguson, 2011). Here, too, attention has been turning towards how technology can be used to support student engagement (Pellegrino \& Quellmalz, 2010; Säljö, 2010; Timmis, Broadfoot, Sutherland, \& Oldfield, 2016).

Past studies have already highlighted several key benefits of online feedback concerning student assessments. Digital approaches are viewed in a favourable light because they help reduce plagiarism (Baker, Thornton, \& Adams, 2008; Batane, 2010) and because they allow for faster marking, thereby reducing the administrative workload (Buckley \& Cowap, 2013). At the same time, feedback - essential to students' learning progression (Gibbs \& Simpson, 2004) - also requires student engagement in order to become as effective as possible, which has been an ongoing concern in higher education (Handley, Price, \& Millar, 2011), and this has not disappeared in the context of technology.

The ongoing Covid-19 pandemic as a particular context has required quicker higher education engagement with online approaches, especially for universities that were not already part of mass online learning (Deng \& Benckendorff, 2020). However, despite the fact that many young people who are now entering higher education are familiar with new technologies, their experiences vary widely and often do not match the new skills required at university, and institutions need to promote appropriate learning opportunities for students to fully engage 
with digital approaches (Newman \& Scurry, 2015). As a result, a renewed look at benefits and drawbacks of online feedback provision will be of benefit to those who seek to provide beneficial higher education experiences.

\section{Key Advantages of Online Feedback}

Under the recognition that online assessment is just as valid as marking hard copy manuscripts (Shaw, 2008), students and faculty alike demonstrate significant preferences for online feedback provision over traditional hard copy formats, and there is a wide range of reasons for such preferences. The initial benefits offered by technology-based approaches such as plagiarism monitoring (Baker et al., 2008; Batane, 2010) and the reported reduced workload for faculty (Buckley \& Cowap, 2013) would initially appear to have no direct impact on students' feedback. However, research has shown that as a result of the advantages for staff, the quality of the feedback that is provided to students typically ends up being more targeted and therefore more effective (Ambler et al., 2014).

Beyond the advantages offered to staff, there are also direct benefits to students. Online assessment and makes for an easier submission process, and access at the feedback stage is also generally considered to be easy (Ambler et al., 2014; Bridge \& Appleyard, 2008; Hast \& Healy, 2016). Legibility of feedback is enhanced since students no longer need to rely on handwritten comments on manuscripts (Bridge \& Appleyard, 2005). Students appreciate the opportunity for remote access (Hepplestone et al., 2011; Parkin, Hepplestone, Holden, Irwin, \& Thorpe, 2012), which can also add the comfort and privacy of the home environment (Hast \& Healy, 2018). Finally, the submitted work with its feedback cannot be lost because it is stored online (Hast \& Healy, 2018), hence remote access also enables repeated access of feedback as opposed to a one-off feedback session in a face-to-face scenario. This means online feedback provision can increase the value that students attach to their assessment feedback (Parkin et al., 2012).

However, time is perhaps the most important advantage to consider. Online feedback approaches save students travel time and travel costs, as well as other costs such as printing of assignments (Bridge \& Appleyard, 2008; Hast \& Healy, 2016). Reduced travel time in particular also affects students' perception of the quality of their work to be submitted because the saved time can be used towards the assignment, particularly with regards to proofreading (Hast \& Healy, 2018). Time also means that accessing feedback online makes the process more convenient and immediate for students (Grieve et al., 2016; Hast \& Healy, 2018; McCabe, Doerflinger, \& Fox, 2011; McGrath \& Atkinson-Leadbeater, 2016). They are able to access their feedback no matter where they are in space or time (Hast \& Healy, 2018; Palmer, 2005; Timmis et al.; Turney et al., 2009), which is entirely in line with the net generation who seeks to engage with their educational experience whenever and wherever they want to (Gosper et al., 2013). Finally, availability of more time means students can engage more carefully with the feedback, which seems to be associated with increased levels academic self-efficacy (Brown et al., 2016), meaning online feedback provision may allow for more self-paced engagement.

\section{Areas of Continued Concern}

There are without a doubt important advantages to online feedback provision approaches. Yet not all that glitters is gold; technology in higher education should not categorically be considered a positive (cf. Selwyn, 2016). Despite the fact that students largely prefer online based approaches when it comes to feedback, such approaches should only be maintained if they serve the students' learning. There are some key areas relating to online feedback that may continue to act as significant barriers to student engagement. If learning engagement as a whole is to be maintained - or indeed to be enhanced - through online feedback, then these barriers must be given careful consideration.

First, even though technology has improved over time, and even though young people are increasingly technology literate, technical issues remain a problem to consider in the context of online feedback provision (Bridge \& Appleyard, 2005; Buckley \& Cowap, 2013). Engaging with online feedback is only possible if there is appropriate technological access. Students themselves express concerns around connectivity as well as having the appropriate skills, and they highlight the importance of not making assumptions about their technology literacy (Hast \& Healy, 2016, 2018). Aspects relating to technology must therefore continue to be taken into account when striving to maximise opportunities of access to feedback.

A core area of importance to consider is students' motivation to access their online feedback. A recent study on access to assessment feedback revealed that more than one third of feedback files had not been accessed by students; a percentage that increased to over $40 \%$ where viewing an assessment mark was possible without viewing a separate feedback file for that assessment (Mensink \& King, 2020) - which was not very different from hard copy feedback engagement (cf. Sinclair \& Cleland, 2007), despite the clear advantages afforded by an 
online approach, such as ease of access or privacy. Often, this was the case because students were focused on scores (Nesbit \& Burton, 2006) and these could be obtained without consulting the feedback. It is therefore necessary to consider ways in which students will be more likely to access their feedback. There are some key student characteristics to consider here. Students who are low performers seem to be less adaptable to online learning environments, seem to interact with online systems less frequently and access their feedback less often (Davies \& Graff, 2005; Harrison et al., 2013; Xu \& Jaggars, 2013).

Combining technical issues, motivation and student characteristics, it is also necessary to realise that virtual learning environments do not provide equitable learning experiences for all its users (Lust, Juarez Collazo, Elen, $\&$ Clarebout, 2012). As a result, the willingness to engage with online feedback provision will vary across the student body. Students may already have expectations of how well they performed, and if the expectation is met through a grade, then students will not be likely to further consult the feedback because there is either little to gain if the mark was positive or because they seek to avoid criticism if the mark was weak - even if anticipated (Carless, 2006; Pitt \& Norton, 2016; Winstone, Nash, Rowntree, \& Parker, 2017). Also, the stakes of the assessment should be considered. Assessments with high importance for a degree result or that have direct implications towards future assessments are more likely to lead to engagement with the provided feedback (Lizzio \& Wilson, 2008).

A further key issue for students is that online feedback, in the absence of face-to-face discussion, can lead to difficulties in the interpretation and implementation of feedback, since there is no immediate opportunity for clarification (Andrade, 2010; Hast \& Healy, 2018; Hattie \& Timperley, 2007). Furthermore, interpretation and use of feedback may differ between students, suggesting that an approach that reduces discussion opportunities may not necessarily be most suitable (Hattie \& Timperley, 2007; McLoughlin \& Luca, 2006). Particularly in light of the benefits afforded by remote access to feedback, there may be delays in the clarification process because students may be accessing their feedback at times where staff are not immediately reachable. This lack of a relationship with the online marker can have knock-on effects, leading towards depersonalisation and reduced self-regulated learning (McCabe et al., 2011; Parkin et al., 2012) and can, in turn, impede the issue of interpretation. In not being able to clarify feedback or having concerns with potential misinterpretation, there is a reduced perceived efficacy to engage (Hast, 2017).

In the context of depersonalisation and motivation, as well as technology literacy, students must be provided with appropriate training, and faculty must not simply assume that students will be able to use relevant platforms in spite of high levels of technology literacy amongst that population (Hast \& Healy, 2018). Indeed, recent research has demonstrated that providing sufficient training in how to access and, perhaps more importantly, process online feedback, can positively support the student transition experience (Hast, 2017). This is probably most particular for students new to higher education and may serve to reduce potential retention issues (cf. Gale \& Parker, 2014; Kift, Nelson, \& Clarke, 2010). Training is important because any lack thereof can have knock-on effects, since leaving students to their own devices may have potential to lead to disengagement with feedback, especially if the cost of effort is too high (McCabe et al., 2011; Parkin et al., 2012).

Finally, most studies in the field examine student perceptions, but few consider the staff viewpoint. While some of the benefits afforded to students are also applicable to faculty, such as remote access to assignments, there are some elements where staff are not unilaterally sympathetic to online feedback provision. McCabe et al. (2011), for instance, noted that lecturers did not see online feedback as being simpler or as more time saving compared to traditional hard copy feedback provision. However, this does seem to be offset by greater detail in the feedback and its perceived effectiveness - both of which should be to the students' advantage (Johnson, Stellmack, \& Barthel, 2019).

\section{Conclusion and Recommendations}

In concluding, it is useful to provide some recommendations with regards to the implementation of online feedback provision, which at least temporarily may be of need to higher education institutions globally. It is quite clear that online feedback stands in connection with many benefits to students and faculty. It would therefore be sensible to enhance awareness of these benefits so that both parties can continue to reap them. This may mean making advantages such as increased quality of feedback and access that is not constrained by time or space more explicit in the student awareness. Training continues to retain its importance. Students may be technology literate, but they still require relevant support structures to understand the particulars of accessing online feedback (Hast, 2017; Hast \& Healy, 2018).

But there remain important areas of concern that may only be exacerbated during tumultuous times for higher education. However, tackling these will hopefully promote student engagement and help higher education as a 
whole to come through the pandemic experience. First, students must be weaned off the approach that only marks matter. Some researchers have proposed the so-called adaptive release - using software that requires opening feedback files before having the mark released (Irwin, Hepplestone, Holden, Parkin, \& Thorpe, 2013; Parkin et al., 2012). This does not guarantee that students will actually engage with the feedback, but it would enhance their awareness of its existence. Ipsative assessment (Hughes, 2011; Hughes, Wood, \& Kitagawa, 2014) could also be used to counteract the effect of the perceived lack of importance of assignments and therefore disengagement with the feedback.

There is also room for more creativity in feedback provision. For example, audio feedback might provide students with some feeling of interaction, something that some students feel is missing in the online text version of feedback (Hast \& Healy, 2018). Several studies have already demonstrated the particular benefits of audio feedback (e.g. Gould \& Day, 2013; Lunt \& Curran, 2010; Parkes \& Fletcher, 2017), and perhaps now is again a time to consider harnessing this tool. Video feedback, although possibly requiring additional resources, could further elevate such student-faculty feedback interactions (e.g. Thompson \& Lee, 2012; West \& Turner, 2016).

\section{References}

Abrahams, D. A. (2010). Technology adoption in higher education: A framework for identifying and prioritising issues and barriers to adoption of instructional technology. Journal of Applied Research in Higher Education, 2(2), 34-49. https://doi.org/10.1108/17581184201000012

Altbach, P. G., Reisberg, L., \& Rumbley, L. E. (2009). Trends in global higher education: Tracking an academic revolution. Paris: UNESCO. https://doi.org/10.1163/9789004406155

Ambler, T., Breyer, Y., \& Young, S. (2014). Piloting online submission and online assessment with Grademark. In S. Kennedy-Clark, K. Everett \& P. Wheeler (Eds.), Cases on the assessment of scenario and game-based virtual worlds in higher education (pp. 125-151). Hershey, PA: Information Science Reference. https://doi.org/10.4018/978-1-4666-4470-0.ch004

Andrade, H. L. (2010). Students as the definitive source of formative assessment. In H. L. Andrade \& G. J. Cizek (Eds.), Handbook of formative assessment (pp. 90-105). New York, NY: Routledge.

Baker, R. K., Thornton, B., \& Adams, M. (2008). An evaluation of the effectiveness of Turnitin.com as a tool for reducing plagiarism in graduate student term papers. College Teaching Methods \& Styles Journal, 4(9), 1-4. https://doi.org/10.19030/ctms.v4i9.5564

Batane, T. (2010). Turning to Turnitin to fight plagiarism among university students. Journal of Educational Technology \& Society, 13(2), 1-12. https://doi.org/10.3126/nelta.v12i1.3440

Bradwell, P. (2009). The edgeless university: Why higher education must embrace technology. London: Demos.

Bridge, P., \& Appleyard, R. (2005). System failure: A comparison of electronic and paper-based assignment submission, marking, and feedback. British Journal of Educational Technology, 36(4), 669-671. https://doi.org/10.1111/j.1467-8535.2005.00485.x

Bridge, P., \& Appleyard, R. (2008). A comparison of electronic and paper-based assignment submission and feedback. British Journal of Educational Technology, 39(4), 644-650. https://doi.org/10.1111/j.1467-8535.2007.00753.x

Brown, G. T. L., Peterson, E. R., \& Irving, S. E. (2009). Beliefs that make a difference: Adaptive and maladaptive self-regulation in students' conceptions of assessment. In D. M. McInerney, G. T. L. Brown \& G. A. D. Liem (Eds.), Student perspectives on assessment: What students can tell us about assessment for learning (pp. 159-186). Charlotte, NC: Information Age.

Brown, G. T., Peterson, E. R., \& Yao, E. S. (2016). Student conceptions of feedback: Impact on self-regulation, self-efficacy, and academic achievement. British Journal of Educational Psychology, 86(4), 606-629. https://doi.org/10.1111/bjep.12126

Browne, T., Jenkins, M., \& Walker, R. (2006). A longitudinal perspective regarding the use of VLEs by higher education institutions in the United Kingdom. Interactive Learning Environments, 14(2), 177-192. https://doi.org/10.1080/10494820600852795

Buckley, E., \& Cowap, L. (2013). An evaluation of the use of Turnitin for electronic submission and marking and as a formative feedback tool from an educator's perspective. British Journal of Educational Technology, 44(4), 562-570. https://doi.org/10.1111/bjet.12054

Carless, D. (2006). Differing perceptions in the feedback process. Studies in Higher Education, 31(2), 219-233. 
https://doi.org/10.1080/03075070600572132

Davies, J., \& Graff, M. (2005). Performance in e-learning: Online participation and student grades. British Journal of Educational Technology, 36(4), 657-663. https://doi.org/10.1111/j.1467-8535.2005.00542.x

Deng, R., \& Benckendorff, P. (2020). Technology-enabled learning. In Z. Xiang, M. Fuchs, U. Gretzel \& W. Höpken (Eds.), Handbook of e-Tourism. Cham: Springer.

Ferguson, P. (2011). Student perceptions of quality feedback in teacher education. Assessment \& Evaluation in Higher Education, 3(1), 51-62. https://doi.org/10.1080/02602930903197883

Gale, T., \& Parker, S. (2014). Navigating change: A typology of student transition in higher education. Studies in Higher Education, 39(5), 734-753. https://doi.org/10.1080/03075079.2012.721351

Gibbs, G., \& Simpson, C. (2004). Conditions under which assessment supports students' learning. Learning and Teaching in Higher Education, 1(1), 3-31.

Gosper, M., Malfroy, J., \& McKenzie, J. (2013). Students' experiences and expectations of technologies: An Australian study designed to inform planning and development decisions. Australasian Journal of Educational Technology, 29(2), 268-282. https://doi.org/10.14742/ajet.127

Gould, J., \& Day, P. (2013). Hearing you loud and clear: Student perspectives of audio feedback in higher education. Assessment \& Evaluation in Higher Education, 38(5), 554-566. https://doi.org/10.1080/02602938.2012.660131

Grieve, R., Padgett, C. R., \& Moffitt, R. L. (2016). Assignments 2.0: The role of social presence and computer attitudes in student preferences for online versus offline marking. Internet and Higher Education, 28, 8-16. https://doi.org/10.1016/j.iheduc.2015.08.002

Handley, K., Price, M., \& Millar, J. (2011). Beyond 'doing time': Investigating the concept of student engagement with feedback. Oxford Review of Education, 37(4), 543-560. https://doi.org/10.1080/03054985.2011.604951

Harrison, C. J., Könings, K. D., Molyneux, A., Schuwirth, L. W. T., Wass, V., \& van derVleuten, C. P. M. (2013). Web-based feedback after summative assessment: How do students engage? Medical Education, 47(7), 734-744. https://doi.org/10.1111/medu.12209

Hast, M. (2017). Supporting student transition to higher education feedback: An evaluation of an online feedback training approach. Journal of Learning Development in Higher Education, Issue 12, Article 2.

Hast, M., \& Healy, C. (2016). Higher education marking in the electronic age: Quantitative and qualitative student insight. Procedia Social and Behavioral Sciences, 228, 11-15. https://doi.org/10.1016/j.sbspro.2016.07.002

Hast, M., \& Healy, C. (2018). "It's like fifty-fifty": Using the student voice towards enhancing undergraduates' engagement with online feedback provision. Journal of Teaching and Learning with Technology, 7(1), 139-151. https://doi.org/10.14434/jotlt.v7i1.23806

Hattie, J., \& Timperley, H. (2007). The power of feedback. Review of Educational Research, 77(1), 81-112. https://doi.org/10.3102/003465430298487

Heinrich, E., Milne, J., \& Granshaw, B. (2012). Pathways for improving support for the electronic management and marking of assignments. Australasian Journal of Educational Technology, 28(2), 279-294. https://doi.org/10.14742/ajet.874

Hepplestone, S., Holden, G., Irwin, B., Parkin, H. J., \& Thorpe, L. (2011). Using technology to encourage student engagement with feedback: A literature review. Research in Learning Technology, 19(2), 117-127. https://doi.org/10.1080/21567069.2011.586677

Hughes, G. (2011). Towards a personal best: A case for introducing ipsative assessment in higher education. Studies in Higher Education, 36(3), 353-367. https://doi.org/10.1080/03075079.2010.486859

Hughes, G., Wood, E., \& Kitagawa, K. (2014). Use of self-referential (ipsative) feedback to motivate and guide distance learners. Open Learning: The Journal of Open, Distance and e-Learning, 29(1), 31-44. https://doi.org/10.1080/02680513.2014.921612

Irwin, B., Hepplestone, S., Holden, G., Parkin, H. J., \& Thorpe, L. (2013). Engaging students with feedback through adaptive release. Innovations in Education and Teaching International, 50(1), 51-61.

https://doi.org/10.1080/14703297.2012.748333 
Johnson, W. F., Stellmack, M. A., \& Barthel, A. L. (2019). Format of instructor feedback on student writing assignments affects feedback quality and student performance. Teaching of Psychology, 46(1), 16-21. https://doi.org/10.1177/0098628318816131

Kift, S. M., Nelson, K. J., \& Clarke, J. A. (2010). Transition pedagogy: A third generation approach to FYE - a case study of policy and practice for the higher education sector. The International Journal of the First Year in Higher Education, 1(1), 1-20. https://doi.org/10.5204/intjfyhe.v1i1.13

Lai, K. W. (2011). Digital technology and the culture of teaching and learning in higher education. Australasian Journal of Educational Technology, 27(8), 1263-1275. https://doi.org/10.14742/ajet.892

Laurillard, D. (2006). E-learning in higher education. In P. Ashwin (Ed.), Changing higher education: The development of learning and teaching (pp. 71-84). London: Routledge.

Lizzio, A., \& Wilson, K. (2008). Feedback on assessment: Students' perceptions of quality and effectiveness. Assessment \& Evaluation in Higher Education, 33(3), 263-275. https://doi.org/10.1080/02602930701292548

Lunt, T., \& Curran, J. (2010). ‘Are you listening please?’ The advantages of electronic audio feedback compared to written feedback. Assessment \& Evaluation in Higher Education, 35(7), 759-769. https://doi.org/10.1080/02602930902977772

Lust, G., Juarez Collazo, N. A., Elen, J., \& Clarebout, G. (2012). Content management systems: Enriched learning opportunities for all? Computers in Human Behavior, 28(3), 795-808. https://doi.org/10.1016/j.chb.2011.12.009

Manuguerra, M., \& Petocz, P. (2011). Promoting student engagement by integrating new technology into tertiary education: The role of the iPad. Asian Social Science, 7(11), 61-65. https://doi.org/10.5539/ass.v7n11p61

McCabe, J., Doerflinger, A., \& Fox, R. (2011). Student and faculty perceptions of e-feedback. Teaching of Psychology, 38(3), 173-179. https://doi.org/10.1177/0098628311411794

McGrath, A., \& Atkinson-Leadbeater, K. (2016). Instructor comments on student writing: Learner response to electronic written feedback. Transformative Dialogues: Teaching \& Learning Journal, 8, 1-16.

McLoughlin, C., \& Luca, J. (2006). Beyond marks and measurement: Developing dynamic and authentic forms of e-assessment. Paper presented at the $23^{\text {rd }}$ annual Australasian Society for Computers in Learning in Tertiary Education conference, Sydney, Australia.

Mensink, P. J., \& King, K. (2020). Student access of online feedback is modified by the availability of assessment marks, gender and academic performance. British Journal of Educational Technology, 51(1), 10-22. https://doi.org/10.1111/bjet.12752

Nesbit, P. L., \& Burton, S. (2006). Student justice perceptions following assignment feedback. Assessment and Evaluation in Higher Education, 31(6), 655-670. https://doi.org/10.1080/02602930600760868

Newman, F., \& Scurry, J. E. (2015). Higher education and the digital rapids. International Higher Education, 26, 13-14. https://doi.org/10.6017/ihe.2002.26.6968

Palmer, S. (2005). An evaluation of on-line assignment submission, marking, and return. Journal of Educational Technology Systems, 34, 57-67. https://doi.org/10.2190/1VDF-ENMR-0KHG-EB82

Parkes, M., \& Fletcher, P. (2017). A longitudinal, quantitative study of student attitudes towards audio feedback for assessment. Assessment \& Evaluation in Higher Education, 42(7), 1046-1053. https://doi.org/10.1080/02602938.2016.1224810

Parkin, H. J., Hepplestone, S., Holden, G., Irwin, B., \& Thorpe, L. (2012). A role for technology in enhancing students' engagement with feedback. Assessment \& Evaluation in Higher Education, 37(8), 963-973. https://doi.org/10.1080/02602938.2011.592934

Pellegrino, J. W., \& Quellmalz, E. S. (2010). Perspectives on the integration of technology and assessment. Journal of Research on Technology in Education, 43(2), 119-134. https://doi.org/10.1080/15391523.2010.10782565

Pitt, E., \& Norton, L. (2016). 'Now that's the feedback I want!' students' reactions to feedback on graded work and what they do with it. Assessment \& Evaluation in Higher Education, 2938, 1-18. https://doi.org/10.1080/02602938.2016.1142500

Prensky, M. (2012). From digital natives to digital wisdom. Thousand Oaks, CA: Corwin. 
https://doi.org/10.4135/9781483387765

Säljö, R. (2010). Digital tools and challenges to institutional traditions of learning: Technologies, social memory and the performative nature of learning. Journal of Computer Assisted Learning, 26(1), 53-64. https://doi.org/10.1111/j.1365-2729.2009.00341.x

Sarkar, S. (2012). The role of information and communication technology (ICT) in higher education for the 21st century. The Science Probe, 1(1), 30-41.

Selwyn, N. (2016). Digital downsides: Exploring university students' negative engagements with digital technology. Teaching in Higher Education, 21(8), 1006-1021. https://doi.org/10.1080/13562517.2016.1213229

Shaw, S. (2008). Essay marking on-screen: Implications for assessment validity. E-Learning and Digital Media, 5(3), 256-274. https://doi.org/10.2304/elea.2008.5.3.256

Sinclair, H. K., \& Cleland, J. A. (2007). Undergraduate medical students: Who seeks formative feedback? Medical Education, 41(6), 580-582. https://doi.org/10.1111/j.1365-2923.2007.02768.x

Thompson, R., \& Lee, M. J. (2012). Talking with students through screencasting: Experimentations with video feedback to improve student learning. The Journal of Interactive Technology and Pedagogy, 1(1), 1-16.

Timmis, S., Broadfoot, P., Sutherland, R., \& Oldfield, A. (2015). Rethinking assessment in a digital age: Opportunities, challenges and risks. British Educational Research Journal, 42(3), 454-476. https://doi.org/10.1002/berj.3215

Turney, C. S. M., Robinson, D., Lee, M., \& Soutar, A. (2009). Using technology to direct learning in higher education: The way forward? Active Learning in Higher Education, 10(1), 71-83. https://doi.org/10.1177/1469787408100196

Walker, R., Voce, J., \& Ahmed, J. (2012). 2012 survey of technology enhanced learning for higher education in the UK. Oxford: UCISA.

West, J., \& Turner, W. (2016). Enhancing the assessment experience: Improving student perceptions, engagement and understanding using online video feedback. Innovations in Education and Teaching International, 53(4), 400-410. https://doi.org/10.1080/14703297.2014.1003954

Winstone, N. E., Nash, R. A., Rowntree, J., \& Parker, M. (2017). 'It'd be useful, but I wouldn't use it': Barriers to university students' feedback seeking and recipience. Studies in Higher Education, 42(11), 2026-2041. https://doi.org/10.1080/03075079.2015.1130032

Xu, D., \& Jaggars, S. S. (2013). Adaptability to online learning: Differences across types of students and academic subject areas. Community College Research Center, 54, 1-32. https://doi.org/10.7916/D82N59NB

\section{Copyrights}

Copyright for this article is retained by the author(s), with first publication rights granted to the journal.

This is an open-access article distributed under the terms and conditions of the Creative Commons Attribution license (http://creativecommons.org/licenses/by/4.0/). 